\title{
Pengembangan Media Animasi Berbasis Sparkol Videoscribe pada Materi Pembuatan Pola Celana Pria di Smk Negeri 1 Batu
}

\author{
Nila Kusumaningtyas, Nur Endah Purwaningsih*, Hapsari Kusumawardani \\ Universitas Negeri Malang, Jl. Semarang No. 5 Malang, Jawa Timur, Indonesia \\ *Penulis korespondensi, Surel: nur.endah.ft@um.ac.id
}

Paper received: 05-04-2021; revised: 18-04-2021; accepted: 21-04-2021

\begin{abstract}
This study aims to develop animation media based on Sparkol Video Scribe on the material making patterns of men's pants at 1 Batu Vocational High School. This is related to the development of technology, so that there is a need for new computer-based media that are more interactive to support the learning process The method used in this research is development research with ADDIE models. Stages of development carried out include: (1) analysis, (2) design, (3) development, (4) implementation, (5) evaluation. The research subjects in this development research were class XII students of the Boutique Clothing Department at 1 Batu Vocational High School totaling 26 students. The developed media contains learning objectives and competencies, the understanding of men's pants and men's pants patterns, sizes, and animated video tutorials for making men's pants patterns. The feasibility of the media that has been made is tested on material experts, media experts and linguists, after being repaired and declared feasible then proceed to the implementation phase of the XII grade students of the Boutique Clothing Department at 1 Batu Vocational High School. The results of expert validation and field trials state that learning media that have been developed are suitable for use with the following results: material expert validation was 92.7 percent, media expert validation was 97.2 percent, language expert validation was 97.5 percent. Data from the field trial results was 92.74 percent. Based on these results it can be concluded that the developed animation media is suitable as a learning media. The media developed are clear, easy to understand and easy to operate, an attractive media display can motivate and attract students to learn because the media can be used as a means of independent learning. Suggestions for further researchers should be the duration in the video tutorial for making men's pants patterns slowed down so that students find it easier to follow the stages of learning.
\end{abstract}

Keywords: learning media; sparkol videoscribe; men's pants pattern

Abstrak
Penelitian ini bertujuan untuk mengembangkan media animasi berbasis Sparkol VideoScribe pada
materi pembuatan pola celana pria di SMK Negeri 1 Batu. Hal ini berkaitan dengan semakin
berkembangnya teknologi, sehingga perlu adanya media baru berbasis komputer yang lebih
interaktif untuk menunjang proses pembelajaran. Metode yang digunakan dalam penelitian ini
adalah penelitian pengembangan dengan model ADDIE. Tahapan pengembangan yang dilakukan
antara lain: (1) analysis, (2) design, (3) development, (4) implementation, (5) evaluation. Subjek
penelitian pada penelitian pengembangan ini adalah siswa kelas XII Jurusan Busana Butik di SMK
Negeri 1 Batu sebanyak 26 siswa. Media yang dikembangkan berisi tujuan pembelajaran dan
kompetensi, pengertian celana pria dan pengertian pola celana pria, ukuran, dan video animasi
tutorial pembuatan pola celana pria. Media yang sudah dibuat terlebih dahulu diuji kelayakannya
pada ahli materi, ahli media dan ahli bahasa, setelah diperbaiki dan dinyatakan layak kemudian
dilanjutkan ke tahap implementasi pada siswa kelas XII Jurusan Busana Butik di SMK Negeri 1 Batu.
Hasil validasi ahli dan uji coba lapangan menyatakan bahwa media pembelajaran yang telah
dikembangkan layak digunakan dengan hasil sebagai berikut: validasi ahli materi sebesar 92,7
persen, validasi ahli media sebesar 97,2 persen, validasi ahli bahasa sebesar 97,5 persen. Data hasil
uji coba lapangan sebesar 92,74 persen. Berdasarkan hasil tersebut dapat disimpulkan bahwa media
animasi yang dikembangkan layak untuk dijadikan sebagai media pembelajaran. Media yang
dikembangkan jelas, mudah dipahami dan mudah untuk dioperasikan, tampilan media yang menarik 
dapat memotivasi dan menarik minat siswa untuk belajar karena media dapat digunakan sebagai sarana belajar mandiri. Saran bagi peneliti selanjutnya sebaiknya durasi pada video tutorial pembuatan pola celana pria diperlambat agar siswa lebih mudah untuk mengikuti tahapan pembelajaran.

Kata kunci: pengembangan media animasi; sparkol videoscribe; pola celana pria

\section{Pendahuluan}

Pemanfaatan teknologi bagi dunia pendidikan sudah merupakan kebutuhan bagi guru maupun siswa. Seiring berkembangnya teknologi, guru dituntut untuk lebih inovatif dalam menyampaikan pembelajaran kepada siswa, salah satunya melaksanakan kegiatan pembelajaran dengan bantuan media interaktif berbasis komputer. Perkembangan teknologi yang semakin pesat tidak hanya menghasilkan teknologi baru saja, namun terdapat juga software-software yang diciptakan, salah satunya ialah Software Sparkol VideoScribe. VideoScribe ialah aplikasi yang digunakan untuk membuat video animasi dengan tulis tangan. Media ini akan menarik minat belajar siswa karena dilengkapi dengan efek animasi, dan juga berisi materi yang dimasukkan ke Software Adobe Flash.

Penelitian pengembangan yang dipilih adalah mengembangkan media animasi berbasis Sparkol VideoScribe pada materi pembuatan pola celana pria. Aplikasi ini sesuai dengan materi yang akan peneliti kembangkan karena berbentuk seperti papan tulis yang cocok digunakan untuk membantu penyampaian materi Pembuatan Pola Celana Pria yang dilakukan secara bertahap (setiap garis beserta keterangannya). Kegiatan belajar mengajar dengan menggunakan media pembelajaran dapat membantu guru dalam menyampaikan materi, selain itu juga memudahkan siswa dalam memahami dan mengakses media sekaligus sebagai sarana belajar mandiri. Hal tersebut sesuai dengan pernyataan Purnama dkk (2016) mengenai pengembangan media video animasi berbasis videoscribe pada materi koloid untuk mahasiswa program studi pendidikan fisika Universitas Syiah Kuala Banda Aceh, pengembangan media video animasi menggunakan sparkol videoscribe dikategorikan sangat baik dengan presentase rerata sebesar 96,6\% dan hasil rekapitulasi angket tambahan mahasiswa secara keseluruhan mahasiswa memberikan tanggapan positif, yaitu sebesar $87,7 \%$ sehingga layak digunakan sebagai salah satu alat bantu dalam proses belajar mengajar.

\subsection{Penelitian Pengembangan}

Menurut Gay (1990) penelitian pengembangan adalah suatu usaha untuk menciptakan produk yang efektif untuk digunakan disekolah, dan bukan untuk menguji teori. Berdasarkan pendapat tersebut, dapat ditarik kesimpulan bahwa penelitian pengembangan adalah suatu proses yang digunakan untuk mengembangkan produk-produk yang dapat digunakan dalam bidang pendidikan. Produk tersebut dapat berupa materi pembelajaran, bahan pelatihan guru, media pembelajaran, soal latihan, dan sistem pengelolaan dalam pembelajaran.

\subsection{Media Pembelajaran}

Latuheru (dalam Hamdani, 2005) memaparkan pengertian dari media pembelajaran yang menyatakan bahwa media pembelajaran adalah alat, bahan atau teknik yang digunakan dalam kegiatan pembelajaran dengan maksud agar proses interaksi atau komunikasi antara guru dan siswa dapat berlangsung secara baik dan berdayaguna. Jadi, dapat diartikan secara 
umum bahwa media pembelajaran ialah alat bantu dalam proses belajar mengajar meliputi segala sesuatu yang dapat digunakan untuk merangsang pikiran, perhatian, perasaan dan kemampuan sehingga dapat mendorong terjadinya proses belajar pada peserta didik.

\subsection{Sparkol VideoScribe}

Sparkol VideoScribe merupakan media komunikasi melalui simbol-simbol (tools) yang dibuat oleh pengirim kepada penerima pesan. Simbol-simbol seperti ikon, kata-kata, kalimat disertai gambar dan audio-visual akan memudahkan penerima untuk memahami pesan yang disampaikan oleh pengirim. Aplikasi ini merupakan sarana yang paling tepat dan akurat karena dapat membantu peserta didik dalam memahami pembelajaran yang disampaikan, selain itu dapat digunakan untuk pengantar pembelajaran. Aplikasi ini memiliki banyak animasi menarik, sehingga dalam kegiatan belajar mengajar siswa akan lebih tertarik dan tidak merasa jenuh.

\subsection{Adobe Flash}

Andi (2010) menyatakan pengertian dari Adobe Flash ialah aplikasi yang digunakan untuk membuat sebuah objek animasi atau objek bergerak. Aplikasi ini dapat dipergunakan untuk beberapa keperluan seperti pembuatan animasi kartun, tampilan presentasi, tampilan interaktif, menu timbal balik, dan dapat juga digunakan sebagai program pendukung desain web.

\subsection{Pola Celana Pria}

Pola merupakan beberapa potongan kain atau kertas yang digunakan sebagai contoh untuk membuat busana, potongan kain atau kertas tersebut mengikuti ukuran dan bentuk badan tertentu (Muliawan, 2001). Sedangkan yang dimaksud dengan pola celana pria adalah potongan-potongan kertas atau kain yang digunakan sebagai contoh dalam menggunting bahan sebelum dijahit menjadi celana pria.

\section{Metode}

Penelitian ini merupakan jenis penelitian pengembangan. Sedangkan model pengembangan yang digunakan adalah model ADDIE yang terdiri dari Analyze (analisis), Design (perancangan), Development (pengembangan), Implementation (implementasi), dan Evaluation (evaluasi). Berikut merupakan bagan alur tahapan model pengembangan ADDIE yang dilakukan:

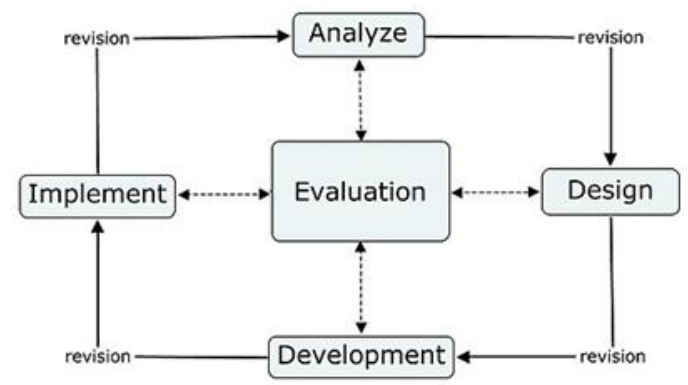

Gambar 1. Bagan Alur Model Pengembangan ADDIE 
Hasil tolak ukur kelayakan pada media pembelajaran yang digunakan pada penelitian pengembangan ini menggunakan skala likert melalui pendapat seseorang atau sekelompok orang. Jawaban dari setiap instrumen diberi bobot dengan interval 1 sampai 4. Penggunaan skala likert dengan empat skala ini tujuannya untuk menghindari jawaban keragu-raguan atau jawaban yang tidak yakin.

Tabel 1. Kriteria Skala Likert

\begin{tabular}{cl}
\hline Angka & \multicolumn{1}{c}{ Makna Kuantitatif } \\
\hline 4 & Sangat baik/sangat layak/sangat mudah/sangat sesuai/sangat tepat \\
3 & Baik/sesuai/mudah/menarik/tepat \\
2 & Cukup baik/cukup sesuai/cukup mudah/ cukup menarik/cukup tepat \\
1 & Kurang baik/kurang sesuai/kurang mudah/kurang menarik/kurang tepat \\
\hline
\end{tabular}

Sumber: Arikunto (2013:285)

Rumus yang digunakan untuk mengolah data dari ahli materi, ahli media, ahli bahasa dan siswa menggunakan persamaan yang diadaptasi dari Akbar dan Sriwiyana (2010:213).

$$
\mathrm{V}-\mathrm{ah}=\frac{T s e}{T s h} \times 100 \%
$$

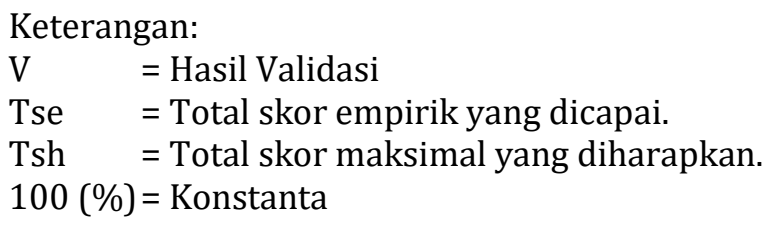

Tabel 2. Penggolongan Presentase Hasil Pengolahan Data

\begin{tabular}{cll}
\hline Presentase & Tingkat Validitas & \multicolumn{1}{c}{ Keterangan } \\
\hline $85 \%-100 \%$ & Sangat Layak & Dapat digunakan tanpa revisi \\
$70 \%-85 \%$ & Cukup Layak & Dapat digunakan dengan revisi kecil \\
$50 \%-70 \%$ & Kurang Layak & Kurang layak digunakan, disarankan tidak digunakan \\
$01 \%-50 \%$ & Tidak Layak & Tidak dapat digunakan \\
\hline
\end{tabular}

\section{Hasil dan Pembahasan}

Tabel 3. Tabel Hasil Implementasi

\begin{tabular}{llcccc}
\hline No & Aspek penilaian & Tse & Tsh & V & Ket \\
\hline 1. & Tampilan Media & 584 & 624 & 93,58 & Sangat Layak \\
2. & Penyajian Materi & 861 & 936 & 91,98 & Sangat Layak \\
3. & Manfaat & 484 & 520 & 93,07 & Sangat Layak \\
& Jumlah & 1.929 & 2.080 & 92,74 & Sangat Layak \\
\hline
\end{tabular}

Berdasarkan hasil tersebut diketahui bahwa aspek tampilan media memperoleh total skor empirik (Tse) sejumlah 584 dari total skor maksimal (Tsh) sejumlah 624. Berdasarkan data tersebut maka diperoleh persentase sebesar 93,58\%, hal ini sesuai dengan kriteria yang terdapat pada tabel 3.2 mengenai penggolongan persentase hasil pengolahan data bahwa hasil tersebut termasuk dalam kategori sangat layak. Berikut merupakan analisis penilaian hasil uji 
lapangan pada kelompok kecil siswa kelas XII Jurusan Busana Butik di SMK Negeri 1 Batu sebanyak 26 siswa berdasarkan aspek tampilan media:

a. Hasil penelitian pada aspek teks yang ditampilkan jelas dan mudah dipahami oleh siswa, diperoleh persentase sebesar $95,15 \%$ artinya bahwa teks pada media pembelajaran yang ditampilkan jelas dan mudah dipahami siswa. Hal tersebut sesuai dengan pernyataan Chee dan Wong (2003) bahwa media yang baik harus memperhatikan kejelasan penulisan berupa pemilihan jenis huruf, ukuran, dan spasi tulisan yang disesuaikan dengan layout yang ada sehingga siswa dapat dengan mudah membaca tulisan yang tertera pada media.

b. Temuan hasil penelitian pada aspek gambar, audio dan video yang ditampilkan jelas dan menarik diperoleh persentase sebesar 93,2\% artinya bahwa gambar, audio dan video yang ditampilkan dalam media pembelajaran sudah jelas dan menarik. Hal tersebut sesuai dengan pendapat Chee dan Wong (2003) bahwa media yang menggunakan gambar, audio, video dan grafik serta animasi yang tepat dapat memberikan ilustrasi proses terjadinya sesuatu dengan tepat dapat memotivasi siswa untuk tertarik mempelajari materi yang disampaikan serta memunculkan keinginan untuk belajar.

c. Berdasarkan temuan hasil penelitian pada aspek tampilan media dapat menarik perhatian siswa diperoleh persentase sebesar 91,3\% artinya bahwa tampilan pada media pembelajaran dapat menarik perhatian siswa. Hal ini sesuai dengan pendapat Arsyad (2002) bahwa penggunaan media pembelajaran dalam kegiatan pembelajaran dapat memotivasi dan meningkatkan keinginan belajar serta karena tampilan media yang menarik akan membuat siswa menjadi lebih tertarik untuk belajar.

d. Hasil penelitian pada aspek media pembelajaran mudah dioperasikan diperoleh persentase sebesar 93,2\% artinya bahwa media pembelajaran ini mudah dioperasikan oleh siswa. Hal tersebut sesuai dengan kriteria penilaian media pembelajaran yang baik menurut Wahono (2006) bahwa media yang memenuhi akses usabilitas atau media yang mudah untuk dioperasikan merupakan kriteria media yang baik.

e. Berdasarkan temuan hasil penelitian pada aspek gambar, audio dan video yang ditampilkan dapat mempermudah siswa mempelajari materi didapatkan persentase sebesar 92,3\% artinya bahwa gambar, audio dan video yang ditampilkan dapat mempermudah siswa dalam mempelajari materi yang terdapat pada media pembelajaran. Hal tersebut sesuai dengan kelebihan multimedia interaktif yang disampaikan Munir (2013) bahwa penggabungan gambar, audio dan video dapat memvisualisaikan materi yang selama ini sulit dijelaskan dengan peraga tradisional sehingga dapat mempermudah siswa dalam memahami materi yang akan disampaikan.

f. Temuan hasil penelitian pada aspek gambar yang ditampilkan sesuai dengan materi pembelajaran diperoleh persentase sebesar $96,15 \%$ artinya bahwa gambar yang ditampilkan pada media pembelajaran sudah sesuai dengan materi.

Hasil temuan pada aspek penyajian materi memperoleh total skor empirik (Tse) sejumlah 861 dari total skor maksimal (Tsh) sejumlah 936. Berdasarkan data tersebut maka diperoleh persentase sebesar 91,98\% sesuai dengan kriteria yang terdapat pada tabel 3.2 tentang penggolongan presentase hasil pengolahan data bahwa hasil tersebut termasuk 
kategori sangat layak. Berikut merupakan analisis penilaian hasil uji lapangan berdasarkan aspek penyajian materi:

a. Berdasarkan temuan hasil penelitian pada aspek penyajian materi ditampilkan secara sistematis diperoleh persentase sebesar $91,3 \%$ artinya bahwa materi yang ditampilkan pada media pembelajaran sudah disusun secara teratur dan runtut. Hal ini sesuai dengan aspek kelayakan penyajian menurut BSNP (Purwono, U. 2008) bahwa penataan sebuah media pembelajaran harus memiliki menu utama, isi dan penutup yang sesuai dengan pedoman.

b. Hasil penelitian pada aspek materi yang disajikan mempermudah siswa dalam memahami materi dan jelas diperoleh persentase sebesar 90,3\% yang artinya ialah siswa mudah memahami materi yang disajikan pada media pembelajaran karena materi yang sudah jelas. Hal tersebut sesuai dengan manfaat media menurut Sudjana dan Rivai (dalam Arsyad, 2014) bahwa agar siswa mudah memahami materi yang disampaikan, maka media pembelajaran harus jelas.

c. Temuan hasil penelitian pada aspek materi ditampilkan secara runtut sesuai dengan urutan tujuan pembelajaran diperoleh persentase sebesar $93,2 \%$ artinya bahwa materi sudah sesuai dengan tujuan pembelajaran dan sudah disajikan secara runtut. Dengan adanya keruntutan materi yang terdapat dalam media pembelajaran, siswa dapat dengan mudah mempelajari materi sehingga tujuan pembelajaran dapat tercapai. Hal tersebut sesuai dengan pendapat Sudjana dan Rivai (1992) mengenai manfaat media pembelajaran bahwa siswa akan dengan mudah memahami materi dan memungkinkan menguasai serta mencapai tujuan pembelajaran jika materi yang disajikan jelas.

d. Berdasarkan temuan hasil penelitian pada aspek teks yang ditampilkan mudah dipahami dan dibaca diperoleh persentase sebesar $94,2 \%$ yang artinya bahwa teks yang ditampilkan pada media pembelajaran mudah dipahami dan terbaca jelas oleh siswa.

e. Temuan hasil penelitian pada aspek kalimat yang digunakan tidak menimbulkan keambiguan (makna ganda) diperoleh persentase sebesar 93,2\% artinya adalah kalimat yang digunakan pada media tersebut tidak menimbulkan keambiguan (makna ganda) sehingga siswa tidak akan bingung. Hal tersebut sesuai dengan pernyataan Harjanto (Sholihah, U., 2018) bahwa penggunaan kalimat harus jelas, komunikatif dan memiliki kualitas yang baik sehingga siswa tidak bingung dalam memahami materi yang disajikan.

f. Hasil penelitian pada aspek istilah-istilah yang dipergunakan mudah dipahami diperoleh persentase sebesar 90,38\% yang memiliki arti bahwa siswa tidak akan bingung ketika menjalankan media karena istilah-istilah yang dipergunakan dalam media mudah dipahami oleh siswa. Hal ini sesuai dengan pernyataan BSNP (Purwono,U 2008) mengenai kriteria aspek kelayakan isi bahwa istilah-istilah yang dipergunakan sesuai dengan kebiasaan yang berlaku dalam bidang ilmu yang akan dipelajari.

g. Temuan hasil penelitian pada aspek kemudahan dalam memahami simbol dan ikon yang dipergunakan diperoleh persentase sebesar 92,3\% artinya bahwa simbol dan ikon yang terdapat dalam media sesuai dengan materi yang disampaikan, selain itu simbol dan ikon jelas dan mudah dipahami siswa. Hal tersebut sesuai dengan kriteria aspek 
kelayakan isi menurut BSNP (Purwono,U. 2008) yang menyatakan bahwa simbol dan ikon yang dipergunakan harus sesuai dengan kebiasaan yang diterapkan dalam bidang ilmu yang akan dipelajari.

h. Berdasarkan temuan hasil penelitian pada aspek bahasa yang digunakan jelas dan mudah dipahami diperoleh persentase sebesar 91,3\% artinya bahwa bahasa yang dipergunakan pada media tidak berbelit-belit, jelas, mudah dipahami siswa dan sudah mengacu pada kaidah Bahasa Indonesia yang baik dan benar. Hal ini sudah sesuai dengan kriteria aspek kelayakan bahasa menurut BSNP (Purwono,U. 2008) yang menyatakan bahwa tata bahasa yang dipergunakan dalam menyampaikan informasi atau pesan harus mengacu pada kaidah tata Bahasa Indonesia yang baik dan benar.

i. Hasil penelitian pada aspek kesesuaian bahasa dengan EYD diperoleh persentase sebesar 91,3\% artinya bahwa bahasa yang digunakan dalam media sesuai dengan EYD (Ejaan Yang Disempurnakan), sehingga jika media pembelajaran menggunakan bahasa tersebut akan sesuai. Hal ini sesuai dengan pernyataan Kasmadi dalam Harjanto (2008) bahwa pemilihan media pembelajaran perlu mempertimbangkan beberapa hal salah satunya pertimbangan isi dalam point pre- sentation, cara penyajian yang benar.

Berdasarkan hasil temuan pada aspek manfaat memperoleh total skor empirik (Tse) sejumlah 484 dari total skor maksimal (Tsh) sejumlah 520. Menurut data tersebut maka diperoleh persentase sebesar $93,07 \%$ sesuai dengan kriteria yang terdapat pada tabel 3.2 tentang penggolongan presentase hasil pengolahan data bahwa hasil tersebut termasuk kategori sangat layak. Berikut merupakan analisis penilaian hasil uji lapangan berdasarkan aspek manfaat:

a. Hasil penelitian pada aspek media pembelajaran mempermudah siswa dalam memahami materi, maka diperoleh persentase sebesar 93,2\% yang memiliki arti bahwa siswa akan mendapatkan kemudahan dalam memahami materi yang disampaikan dengan media pembelajaran yang telah dikembangkan. Hal ini sudah sesuai dengan pernyataan Hamalik (dalam Arsyad, 2002) mengenai manfaat media pembelajaran bahwa siswa akan lebih mudah memahami materi yang disampaikan dengan adanya media pembelajaran.

b. Berdasarkan temuan hasil penelitian pada aspek penyajian materi media pembelajaran mampu meningkatkan minat siswa untuk mempelajari materi diperoleh persentase sebesar 94,2\% yang memiliki arti bahwa minat siswa untuk mempelajari materi akan muncul dengan menggunakan media pembelajaran yang telah dikembangkan. Hal tersebut sesuai dengan pendapat Brigs (dalam Sadiman, 2002) mengenai manfaat media pembelajaran yang menyatakan bahwa media dapat merangsang minat siswa untuk belajar dan dapat menyajikan pesan.

c. Temuan hasil penelitian pada aspek tampilan media pembelajaran mampu meningkatkan minat siswa untuk mempelajari materi, maka diperoleh persentase sebesar 92,3\% yang artinya bahwa ketertarikan siswa akan muncul untuk mempelajarai kembali materi yang terdapat pada media pembelajaran karena tampilan media pembelajaran yang dikembangkan menarik. Hal ini sesuai dengan manfaat media pembelajaran yang disampaikan Hamalik (dalam Arsyad, 2002) bahwa media 
pembelajaran dapat membangkitkan minat dan keinginan yang baru, serta merangsang dan membangkitkan motivasi siswa untuk belajar.

d. Hasil penelitian pada aspek media pembelajaran meningkatkan motivasi siswa untuk mempelajari materi diperoleh persentase sebesar 93,2\% artinya bahwa media pembelajaran yang telah dikembangkan mampu meningkatkan motivasi siswa untuk mempelajari materi. Hal tersebut sesuai dengan pendapat Rowntree (dalam Rohani, 1997) yang memaparkan bahwa media pembelajaran harus dapat mengulang materi yang telah diajarkan dan membangkitkan motivasi belajar, sehingga siswa selalu termotivasi untuk belajar.

Temuan hasil penelitian pada aspek media pembelajaran dapat meningkatkan hasil belajar siswa diperoleh persentase sebesar 92,3\% yang memiliki arti bahwa materi yang disajikan dalam media pembelajaran mudah dipahami sehingga siswa mampu meningkatkan hasil belajarnya. Hal ini sesuai dengan pernyataan Thorn dalam Munir (2009) yang berpendapat bahwa program yang dikembangkan harus memberikan pembelajaran yang dapat meningkatkan hasil belajar.

\section{Simpulan}

Hasil yang didapat pada aspek tampilan media yaitu teks yang ditampilkan sudah jelas dan mudah dipahami oleh siswa. Gambar, audio dan video yang ditampilkan pada media pembelajaran jelas dan menarik perhatian siswa. Tampilan media menarik perhatian siswa sehingga siswa tertarik untuk belajar. Gambar, audio dan video yang ditampilkan pada media pembelajaran dapat mempermudah siswa mempelajari materi yang disampaikan, selain itu gambar yang ditampilkan sesuai dengan materi pembelajaran pembuatan pola celana pria. Hasil temuan yang didapat pada aspek penyajian materi yaitu penyajian materi yang ditampilkan runtut dan sistematis, materi yang disajikan dalam media pembelajaran sudah jelas dan mudah dipahami oleh siswa. Materi yang disajikan pada media pembelajaran sudah sesuai dengan urutan tujuan pembelajaran. Selain itu, dari segi teks, kalimat, istilah, simbol dan ikon yang digunakan mudah dipahami karena sesuai dengan materi pembelajaran. Bahasa yang digunakan dalam media pembelajaran mudah dipahami dan sesuai dengan EYD. Berdasarkan hasil yang didapat dari aspek manfaat, media pembelajaran ini mempermudah siswa dalam memahami materi pembuatan pola celana pria. Penyajian materi pada media pembelajaran ini mampu meningkatkan minat siswa untuk mempelajari materi yang telah disampikan. Tampilan media pembelajaran yang menarik juga mampu meningkatkan minat siswa untuk mempelajari materi.

\section{Daftar Rujukan}

Sriwiyana, H., \& Akbar, S. D. (2010). Pengembangan Kurikulum Dan Pembelajaran Ilmu Pengetahuan Sosial (IPS).

Sunyoto, A. (2010). Adobe Flash+ XML= Rich Multimedia Application. Yogyakarta: Andi.

Suharsimi, A. (2006). Prosedur penelitian suatu pendekatan praktik. Jakarta: Rineka Cipta, 120-123.

Arsyad, A. (2002). Media Pembelajaran Jakarta: Raja Grafindo Persada.

Tan, S. C., \& Wong, A. F. (Eds.). (2003). Teaching and learning with technology: An asia-pacific perspective. Pearson/Prentice Hall.

Mills, G. E., \& Gay, L. R. (2019). Educational research: Competencies for analysis and applications. Pearson. One Lake Street, Upper Saddle River, New Jersey 07458.

Hamdani, H. (2005). Manfaat Media Pembelajaran. Jakarta: Pustaka Cipta. 
Jurnal Inovasi Teknik dan Edukasi Teknologi, 1(4), 2021, 274-282

Harjanto, H. (2008). Perencanaan Pengajaran. Jakarta: Rineka Cipta.

Muliawan, P. (2001). Pengertian Pola. Jakarta: PT BPK Gunung Mulia.

Munir, D., \& IT, M. (2009). Pembelajaran jarak jauh berbasis teknologi informasi dan komunikasi. Bandung: Alfabeta, 24 .

Munir, D. (2013). Multimedia dan Konsep Aplikasi Dalam Pendidikan. Bandung: Penerbit Alfabeta.

Purwono, U. (2008). Standar Penilaian Buku Pelajaran. Jakarta: Universitas Terbuka.

Purnama, P., \& Nazar, M. (2017). Pengembangan Media Video Animasi Berbasis Videoscribe Pada Materi Koloid Untuk Mahasiswa Program studi Pendidikan Fisika Tahun Akademik 2016/2017. Jurnal Ilmiah Mahasiswa Pendidikan Kimia, 2(3).

Rohani, A. (1997). Media intruksional Edukatif. Jakarta: PT Rineka Cipta.

Sholihah, U. N., \& Suhartini, R. (2018). Pengembangan Media Pembelajaran Modul Virtual pada Materi Busana Casual Pria. Jurnal Tata Busana, 7(2).

Wahono, R. S. (2006). Aspek dan kriteria penilaian media pembelajaran. Online) (http://romisatriawahono. net/, diakses pada tanggal 20 Mei 2016). 